\title{
IT self-employed workers between constraint and flexibility
}

\section{Diane-Gabrielle Tremblay and Emilie Genin}

\begin{abstract}
This research focuses on the degree of work autonomy which IT self-employed workers enjoy. It relies on quantitative and qualitative data. We found that strategic autonomy (ability to choose one's work objectives) is linked to individual characteristics: education and expertise, whereas operational autonomy (ability to choose the adequate methods) is correlated to contextual factors such as the type of clients and the kind of contracts.
\end{abstract}

\section{Introduction}

In many industrialised countries, self-employment has become one of the main sources of new jobs (Moore and Mueller, 2002; Tal, 2008), and it is expected that selfemployment will continue to develop in the coming years. ${ }^{1}$ Indeed, organisational and individual strategies seem to converge in that direction, and the recent context of crisis might increase self-employment as firms cut regular jobs and resort to contracts. On the one hand, organisational boundaries are increasingly blurred (Robinson and Miner, 1996) while non-standard employment grows steadily (Tremblay, 2004; 2008); organisations in both the private and the public sectors call upon more and more subcontractors for specialised or general tasks (Lepak and Snell, 1999). On the other hand, project management, a now common form of work organisation (Lepak and Snell, 1999), lends itself easily to subcontracting. Subcontractors such as external consultants and selfemployed workers are often called upon to collaborate with permanent employees for the duration of a specific project (Ang and Slaughter, 2001).

$\square$ Diane-Gabrielle Tremblay (dgtrembl@teluq.uqam.ca) is Canada Research Chair on the SocioOrganisational Challenges of the Knowledge Economy and Director of the Community-University Research Alliance on Work-Life Balance over the Lifecourse. She is Professor of Labour Economics and HRM at the Télé-Université of l'Université du Québec à Montréal, Canada. Émilie Genin (emilie.genin@ umontreal.ca) is an invited professor in Human Resources Management at the École de relations industrielles, Université de Montréal. During this research she was postdoctoral researcher at the Canada Research Chair on the Socio-Organizational Challenges of the Knowledge Economy. 
Many authors view self-employment as a win-win solution for both individuals and organisations (Lepak and Snell, 1999; Inkson and Arthur, 2001). It may be expected, therefore, that self-employment will become a widespread, run-of-the-mill working format in industrialised countries. Other researchers (Stanworth and Stanworth, 1997; Marler et al., 2002; Guest et al., 2006), however, question the advantages of selfemployment and emphasise that the interdependent relationships between selfemployed workers and clients are complex (D'Amours and Crespo, 2004). It is thus useful to study such work forms in more detail (Rogers, 2000).

In order to shed some light on the relations between self-employed workers and their clients, we focused on the characteristics of autonomy of self-employed workers in the IT sector. The rise of subcontracting is a notable trend in the IT sector (Ang and Slaughter, 2001), and Cappelli (2001) notes that the market for IT workers has been very tense in the past years. Businesses encounter personnel recruitment problems, and some can hardly offer competitive salaries to attract them. Many call on external suppliers as an alternative to the shortage of qualified personnel or to control their costs (Lepak and Snell, 1999). It follows that contracting out IT services for specific projects has developed into a common practice over the past 15 years (Ang and Slaughter, 2001; Cappelli, 2001). Market demand is thus satisfied not only by large consulting firms but also by an increasing number of IT self-employed workers. For example, Ang and Slaughter (2001) estimate that the number of IT freelance workers in the USA has grown by 40 per cent between 1995 and 1998. Information and communication technologies (ICTs) in general is a sector in which self-employment has increased considerably.

Also to be noted, today's IT workers are often highly qualified (Ang and Slaughter, 2001; Cappelli, 2001). Their worth on the labour market should provide them a real bargaining power with their clients and significant autonomy in the performance of their job (Lepak and Snell, 1999; Inkson and Arthur, 2001). Nevertheless, other studies reveal a rather limited degree of autonomy, including for qualified self-employed workers (Stanworth and Stanworth, 1997).

Consequently, the purpose of this article is to discuss the degree of autonomy that self-employed workers really enjoy. To do so, we used a research methodology that is both quantitative and qualitative. Our results highlight the links between individual and contextual factors and shed light on two facets of work autonomy (strategic and operational). But before, let us go over the definition of self-employment, the meaning of autonomy that is usually attached to this status, as well as the identification of various types of self-employment.

\section{Definition of self-employment}

Political, social and economic actors do not agree on a common definition of selfemployment. Although the expression self-employed worker is most commonly used, the independent person may be distinguished from other self-employed persons who hire help. In the last census, Statistics Canada included in the self-employment category those persons who operate a farm either as owner or tenant; workers, for example, freelancers or contract workers; franchise or concession holders in the sale or direct distribution of products such as cosmetics, newspapers, brushes or household products; and those who fish, either with personally owned equipment or equipment of which they are co-owners.

A more inclusive definition, however, may be attached to self-employment in reference to the entrepreneur, the contract worker, the freelancer, the craftsperson, and to three types of professionals: fee-for-service, commission or contract, and finally the daily labourer or jobber (Tremblay et al., 2006; Tremblay, 2008). For the purpose of our research and in keeping with Delage's (2002) investigation on independent work, we shall consider self-employed workers as those who are independent (on their own, without hired help), self-employed workers who hire a very limited number of employees, most often only occasionally, freelancers under contract, and professionals in co-partnership on an individual basis. 
- cover their own work-related expenses;

- assume the financial risks associated with their work;

- provide their own tools or equipment but are not obliged to perform the work themselves;

- may hire employees or other self-employed persons to do the job;

- may determine the location at which the work is to be carried out and the hours of work.

In other words, they are independent of their clients (Revenu Québec, 2007). In spite of this alleged autonomy, practices are often different, and that is why it appeared interesting to research this issue of the work autonomy of self-employed workers. The next section presents a short review on work autonomy, and then we will see why this notion may have different meanings for different types of self-employed workers.

\section{The meaning of autonomy}

Van Gelderen and Jansen (2006) note that a certain consensus has emerged around the general notion of autonomy, that is, the individual capacity to make one's own choices beyond the control of others. However, the concept of work autonomy remains polysemous, and a majority of authors agree that it is a multidimensional concept. Breaugh (1999) identifies three facets of the concept: work method autonomy (degree of choice individuals have regarding procedures/methods they use), work scheduling autonomy (extent to which workers feel they can control the scheduling/timing of their work activities) and criteria autonomy (extent to which workers can choose or modify the criteria used for evaluating their performance). Guérin et al. (1999) distinguish between strategic autonomy, which allows workers to choose their work objectives and goals, and operational autonomy, which authorises them to choose the adequate methods to resolve problems or to reach fixed targets.

Other authors prefer the notion of discretion to the concept of work autonomy (de Terssac, 1992; de Terssac and Maggi, 1996). Indeed, discretion refers to the freedom of action through which workers may choose among different options, although in a constrained environment. The concept of discretion thus indicates that work autonomy is always limited by organisational constraints, which is consistent with the results of Janz et al. (1997), who indicate that the interdependence between the members of a team is the first factor limiting work autonomy.

Alvesson and Willmott (2002) use the term of micro-emancipation to define situations in which workers gain marginal autonomy. These micro-emancipations involve a slackening of organisational constraints but are accompanied by increased stress and job insecurity. For example, workers can benefit from more flexibility to define their working methods but have to respect strict quality and quantity parameters fixed by the organisation. Alvesson and Willmott (2002) and Willmott (1993) clearly insist on the limitations of work autonomy.

Where self-employed workers are concerned, the traditional employer-employee relationship is replaced by an interdependent relationship between a client and a supplier (Lepak and Snell, 1999). Further, and in keeping with their qualifications and their worth on the market, independent IT contractors are often viewed as knowledge workers (Ang and Slaughter, 2001). We would therefore expect that they would enjoy a substantial degree of work method autonomy and work scheduling autonomy (Breaugh, 1999) or operational autonomy (Guérin et al., 1999). Moreover, their knowledge should also enable them to negotiate their goals and duties (strategic autonomy in Guérin et al., 1999). However, recent research questions the benefits of self-employment in terms of flexibility and autonomy (Marler et al., 2002; Beaucage and Bellemare, 2007). Consequently, it seems particularly interesting to investigate more in depth the notion of work autonomy among self-employed workers. 


\section{Various types of self-employed workers and degrees of autonomy}

A number of authors underscore the necessity of distinguishing various groups of self-employed workers with respect to their qualifications and their worth on the labour market (Rogers, 2000; Marler et al., 2002). Smeaton (2003) notes that the development of self-employment is generally associated with two opposite models: the optimistic portfolio model essentially concerns qualified professionals, and the pessimistic model of marginalisation is closer to the job insecurity of less qualified workers.

The portfolio model owes much to the knowledge economy (Castells, 2000) because knowledge is highly valued on the labour market. Given their scarcity and the worth of their knowledge, these workers would enjoy a beneficial negotiating position to deal with their job or service (Cappelli, 2001; Kunda et al., 2002). In addition, they may negotiate valuable arrangements in terms of compensation and working conditions.

While some have reservations about IT workers being the archetype of the knowledge worker, numerous analogies can be drawn between the conditions prevalent in self-employment with that of knowledge workers in general (Donnely, 2006; Beaucage and Bellemare, 2007), which again emphasises the blurring of boundaries in terms of job status. Consequently, the issue of the autonomy of self-employed workers questions the emergence of new work models, hybrid status, between independence and organisational constraints.

Indeed, the definition of 'knowledge work' remains vague. Fincham (2006) and Rose (2002) suggests that IT competence is not necessarily associated with power in organisations. Marks and Scholarios (2007) underline a polarisation in the profession based on qualifications. In the IT sector, the job market is shared by highly qualified individuals on one side-the knowledge workers - and a class of technicians more often assigned to execution tasks and not involved in design activities. Finally, Westenholz (2006) rejects the relevance of applying one model to understand the working conditions of temporary company-affiliated IT workers; she suggests that different models (precarious, free agent or professional) may be relevant for different aspects of their work.

In the same vein, other authors have examined boundaryless careers (Arthur and Rousseau, 1996; Inkson and Arthur, 2001): freed from organisational constraints, knowledge workers should gain control over their professional destiny. Self-employed workers would be in a position to secure all the available opportunities in terms of flexibility, mobility and control over their activities (Lepak and Snell, 1999; Inkson and Arthur, 2001). Self-employment would give individuals and organisations added efficiency and productivity (Lepak and Snell, 1999; Inkson and Arthur, 2001); it would offer stimulating personal development and career opportunities (Bradley and Roberts, 2004; Peel and Inkson, 2004).

One of the central elements of the portfolio model is therefore associated with selfdetermination and the resulting non-monetary benefits (Hamilton, 2000; Smeaton, 2003). Other studies also show that the decision to start a business is often motivated by a thirst for self-reliance (Hamilton, 2000; Smeaton, 2003; Van Gelderen and Jansen, 2006). Further, Beaucage and Bellemare (2007) assert that self-employed workers who are satisfied with their status are more attracted to autonomy and self-reliance in their work than dissatisfied self-employed workers.

Loscocco (1997) examines the diversity of self-employment situations. In this study, all respondents whole-heartedly display their enthusiasm for the flexibility they enjoy as self-employed workers, especially with time issues. However, women indicate more often than men work-family balance as an outcome of such flexibility, which is not a surprise because research on self-employment often identifies situations and motivations specific to women (Boden, 1999; Felstead and Jewson, 2000; Heller Clain, 2000; Smeaton, 2003; Beaucage et al., 2004; Beaucage and Najem, 2006).

Elsewhere, the portfolio model has been decisively challenged. Felstead et al. (2002) found that workplace flexibility represents a privilege for workers already occupying an advantageous position in the labour market. 
Some work also shows that the self-employed workers enjoy more job satisfaction than salaried workers do (Blanchflower, 2000; Hundley, 2001; Parasuraman and Simmers, 2001). For Hundley (2001), self-employed workers are more satisfied because their status provides them more flexibility and opportunities to develop their skills. Nevertheless, Guest et al. (2006) found no significant difference in the work satisfaction and stress level between self-employed and salaried workers.

In the IT sector, however, Ang and Slaughter (2001) show that where self-employed workers are indeed more satisfied with their jobs than wage earners, the supervisors generally trust them less. Mistrust towards self-employed workers leads clients to monitor them more closely and intensively. Paradoxically, there would be fewer controls on salaried employees than on self-employed workers!

In order to enjoy the freedom and the autonomy inherent to self-employment, self-employed workers must have high levels of expertise and skills that are rare on the labour market (Marler et al., 2002). Peel and Inkson (2004) contend that self-employed workers' independence is contingent on such factors as expertise, clients and market. Finally, Stanworth and Stanworth (1997) suggest that even qualified workers are sometimes drawn to self-employment because that is the only option available. The authors observe that some self-employed workers are extremely dependent on one or two major clients and that their autonomy and negotiating range is severely curtailed.

Hyytinen and Ruuskanen (2007) found that Finnish self-employed workers' perception of independence is based essentially on the flexibility they enjoy in organising their work schedules. Average working hours, however, are 20 per cent longer than those of wage earners; further, the self-employed experience more stress and pressure. Their work impinges more often on their personal and leisure times. The authors therefore conclude that the time flexibility that self-employed workers enjoy comes at a price and that their independence must be assessed through the prism of resulting constraints.

Likewise, Evans et al. (2004) observed a definite distortion between the flexibility that IT self-employed workers claim to enjoy and what they make of it in practice. Indeed, IT self-employed workers make little use of the possibilities offered by independent work in terms of holidays and flexible schedules. They work long hours and their schedules are almost as rigid as those of salaried workers.

Three types of explanation are proposed to explain the phenomenon (Kunda et al., 2002; Evans et al., 2004). First, self-employed workers accept all the contracts they are offered because they fear or anticipate periods of inactivity. Second, they are usually paid by the hour. They therefore tend to calculate the opportunity cost of the activities they cannot bill to a client. Finally, organisations often call them in periods of crisis. Their workload becomes very heavy; they must perform quickly, and this entails long working hours. The studies by Evans et al. (2004) and by Kunda et al. (2002) thus question the notion of flexibility that independent IT workers actually enjoy in terms of work schedule.

Various studies suggest that those relationships between self-employed workers and client organisations are far from simple (Marler et al., 2002). Donnely (2006) argues that the interdependent relationships with clients-and the scope of the trade-off involved-remain rather undefined. Following the results of Marks and Scholarios (2007) and Westenholz (2006), we can make the hypothesis that 'professionals' enjoy more autonomy than 'technicians'. We also assumed that the level of autonomy depends on the client (Peel and Inkson, 2004; Beaucage and Bellemare, 2007). Consequently, our general hypothesis is that the work autonomy of IT self-employed workers depends on contextual factors (clients) and on personal factors (expertise and experience):

Hypothesis 1a: Professionals enjoy more work autonomy than technicians.

Hypothesis $1 \mathrm{~b}$ : Work autonomy depends on the type of client.

Studying IT self-employed workers is doubly interesting. First of all, it questions the specificities of the IT sector, where the workforce is generally in high demand. On the one hand, we probe the leeway afforded to them within the complex set of relationships 
with clients, and on the other we shed light on the factors likely to affect their level of independence. To this end, we focus on strategic and operational autonomy of IT selfemployed workers, and we illustrate this with the example of the ability to choose their workplace. Indeed, a previous study had highlighted an acute distortion between the practices of IT independent workers and their expectations with respect to work location (Tremblay and Genin, 2007).

\section{Method}

This research is part of an investigation conducted in collaboration with the Quebec Association of IT Freelance Workers (AQIII). The AQIII reports a 20 per cent average increase of its membership per annum since 2003, which confirms the rapid development of self-employment in the IT sector. Data were collected electronically in the spring of 2007. An email was sent to the 700 members of the professional association with a hyperlink to the online questionnaire. The number of participants in our investigation (116) represented 18 per cent of the association membership. We also conducted 10 semi-structured interviews with members of the association in order to gain a better understanding of the quantitative data.

\section{Profile of respondents}

A large majority of respondents were men (82 per cent). The percentage of women who participated (18 per cent) was larger than the percentage of female members of the association (11 per cent), and the respondents were relatively young: 71 per cent of them were aged 44 or younger and 53 per cent were between 35 and 44 years of age. More than 80 per cent of the respondents were living with a spouse or partner and 55 per cent with one or more dependent children. To a large extent, our respondents worked alone: 83 per cent had neither employees nor subcontractors. The average seniority in terms of self-employment was 7.5 years and the average professional experience in IT was 17 years. This means that most respondents had acquired extensive experience in IT before going on their own.

The questionnaire first established a general socio-demographic profile of individual participants. Respondents were asked questions on different aspects of their work autonomy: deadlines, outcomes, financial resources, workplace, holidays, equipment and tools, and work procedures and techniques. For each proposition they were asked how it was decided: by themselves, by the client or by negotiated terms and conditions.

In addition, participants were required to indicate the usual distribution of their workplaces (in hours per week) as well as the ideal distribution they aspired to; in an open-ended question, participants were required to explain the reasons for this preference. Regarding the specificity of self-employment, the enquiry included a trail of open-ended questions on work organisation, work arrangements and frequency of work from home.

We did a factor analysis of the seven aspects of work autonomy in order to summarise the information. Using the scores (regression method in SPSS) derived from the items that fall into the factors, we analysed the effects of contextual, individual and demographic variables on work autonomy. We conducted correlation analyses between the factors with gender, dependents' (one or more children under 12) age, status (single or couple), number of years as self-employed and number of years of experience in the IT sector.

Following our Hypothesis 1a we distinguished our respondents according to their qualification.

Hypothesis 1a: Professionals enjoy more work autonomy than technicians.

We coded 2 those with at least one completed university degree and 1 those without a university degree. The code 1 should thus correspond to 'technicians' and the code 2 to 'professionals'. We also conducted correlation analysis with the hourly rate charged by our respondents to get an idea on her or his level of expertise and experience. 
We also hypothesised that the level of autonomy depends on the client.

Hypothesis 1b: Work autonomy depends on the type of client.

Consequently we asked questions on the type of clients they worked with (big companies, small and medium size businesses (SMB), etc.). Finally respondents were asked how they were paid (by the hour or a fixed amount negotiated with the contract).

We also conducted semi-structured interviews with 10 members of the AQIII (7 men and 3 women aged between 33 and 55) in order to collect information, allowing a better interpretation of the quantitative data. All the interviews were recorded; transcripts were produced and coded with Nvivo. The interviews explored the following themes:

- respondents' socio-demographic profile;

- career path, experience and current independent worker status;

- control factors relating to work outcomes and to working times and workplaces;

- questions on work autonomy perception, negotiations with clients and demands that were refused by clients.

The coding of individual respondents was structured as follows: gender, age, number of years as a self-employed worker.

Example: F, 50, 4 (female, 50 years old, self-employed for 4 years).

\section{Results}

Table 1 presents the results (in percentage) on work autonomy. With principal component analysis (see appendix), we found two factors summarising these aspects of work autonomy.

These factors fit with the typology of Guérin et al. (1999). The first factor corresponded to what Guérin et al. (1999) called strategic autonomy, that is, the ability to negotiate the deadlines, the outcomes and financial resources of the mandate. The second factor included what Breaugh (1999) called work scheduling autonomy and work method autonomy while Guérin et al. (1999) referred to operational autonomy. We therefore decided to call this factor operational autonomy; it is composed of the following items: workplace, holidays, equipment and tools, and work procedures.

We conducted correlation analyses between organisational and individual variables and the degrees of strategic and operational autonomy (correlation coefficients for the two-tailed tests are presented in Table 2).

\section{Strategic autonomy}

We found that strategic autonomy was highly correlated to education (university degree) and to the hourly rate of our respondents regardless of age, gender or years of

Table 1: How are these elements determined? (\%)

\begin{tabular}{llll}
\hline & $\begin{array}{l}\text { Decides by } \\
\text { himself or } \\
\text { herself }\end{array}$ & $\begin{array}{l}\text { Negotiated } \\
\text { terms and } \\
\text { conditions }\end{array}$ & $\begin{array}{l}\text { Client } \\
\text { prescribes }\end{array}$ \\
\hline Deadlines & 6 & 60 & 32 \\
Outcomes & 6 & 54 & 39 \\
Financial resources & 2 & 36 & 61 \\
Workplace & 11 & 42 & 46 \\
Holidays & 43 & 55 & 2 \\
Equipment and tools & 15 & 47 & 38 \\
Work procedures and techniques & 23 & 54 & 21 \\
Totals are below 100 where some respondents have replied 'other' & \\
\hline
\end{tabular}




\begin{tabular}{lll}
\hline & $\begin{array}{l}\text { Strategic } \\
\text { autonomy }\end{array}$ & $\begin{array}{c}\text { Operational } \\
\text { autonomy }\end{array}$ \\
\hline University degree & $0.290\left(^{* *}\right)$ & NS \\
Hourly rate & $0.249\left(^{* *}\right)$ & NS \\
Percentage of hourly paid contracts & NS & $-0.248\left(^{*}\right)$ \\
Percentage of fixed price contracts & NS & $0.232\left(^{*}\right)$ \\
Percentage of SMEs as clients & NS & $0.284\left(^{*}\right)$ \\
\hline
\end{tabular}

${ }^{*}$ Correlation is significant at the 0.05 level (2-tailed).

**Correlation is significant at the 0.01 level (2-tailed).

NS = Non significant.

experience in IT. We can suppose the hourly rate reflects both qualification and expertise. Strategic autonomy was thus linked to individual characteristics: education and expertise. The interviews also indicated that the degree of strategic autonomy increased with the level of qualification and expertise:

The more you are specialised and have expertise, the more you will have security. It is an economic situation or a tendency in IT ... I am in an expertise with a workforce shortage ... To me, the most important autonomy is to be able to choose my clients, working environment and the project I am working on. I can do that now because of my expertise. (M, 40, 10)

The differences in strategic autonomy reflected the dichotomy in the IT sector between technicians and professionals. In self-employment, technicians are contracted for a precise mandate with a relatively low degree of strategic autonomy whereas professionals tend to consider themselves as consultants with a higher degree of strategic autonomy:

I do not consider myself as a contractor but as a consultant; I want to explain the difference between the two. When you work as a contractor, you are paid by the hour, but as a consultant, time is not so important. You are here to propose solutions; you negotiate the objectives of your mission. ... You can propose to extend or to reorient your mandate. (M, 42, 4)

The different degrees of strategic autonomy may thus reflect the differences between 'technicians' and 'professionals'.

\section{Operational autonomy}

Operational autonomy was linked to contextual factors such as the percentage of SMEs as clients and the mode of payment (contract paid by the hour or for a fixed price).

Our respondents seemed to enjoy a greater degree of operational autonomy in SMEs than in big companies. In SMEs, they generally dealt directly with the chief executive, whereas in big companies, they had to deal with more hierarchical levels, which could explain why they enjoyed less operational autonomy. Another point to mention is that big companies had more formal rules than SMEs, and they tended to apply these rules to self-employed as well as salaried workers. For example, it was not uncommon that self-employed workers were denied the possibility to telework, or work from home, because no such provision was available to permanent employees. Moreover, big companies were often reluctant to allow more operational autonomy to self-employed workers because this could be interpreted as a privilege and create frustration among permanent employees:

When telework turns into a habit for employees, it will be easier for the consultants. . . If telework is allowed for the consultants only, you can be sure that permanent employees will express their frustration. (M, 40, 7) 
Of course you have a better salary (than permanent employees) so you can't claim more. If permanent employees are denied telework, you're not getting it either! $(\mathrm{F}, 50,4)$

Labour laws clearly state that the self-employed worker is not salaried. There should therefore be no relation between the work policy for wage earners and the conditions that apply to self-employed workers. Yet a number of organisations deny operational autonomy to self-employed workers, arguing that this would create frustration among employees. This inconsistency underlines the blurring of employment status between self-employed workers and wage earners and the porosity of organisational boundaries in terms of who belongs to the organisation and who does not. This permeability at the boundary has consequences not only on self-employed workers who finally accept to abide by the rules that govern wage earners but also on client organisations who are then confronted with a new type of human resources management problem: how to manage the frustrations and the differences between salaried workers and the increasing number of outside suppliers.

Technically, the status of the self-employed is not in a regulatory vacuum. Yet practices such as the independent workers' respect of organisational policies question the applicability of the pure independence model in a world of interdependence.

On the contrary, the interviews suggested that there were less formal rules in small companies, so it was easier for self-employed workers to negotiate operational autonomy.

The smaller the organisation, the less structured it is. (M, 44, 21)

The mode of payment of the contract (paid by the hour or a total fixed price) was correlated to operational autonomy. Indeed, the percentage of hourly paid contracts was negatively linked to operational autonomy whereas the percentage of fixed price contracts was positively correlated to operational autonomy. Consequently, it seemed that hourly paid contracts tended to reduce operational autonomy, especially as concerns the choice of workplaces. If our respondents were paid by the hour, many clients denied them telework because they feared that self-employed workers would not perform all the working hours they were paid for. Clients apparently preferred to keep an eye on them. In the interviews, the question of trust between self-employed workers and clients came among the main reasons why operational autonomy was limited:

Actually, what they (clients) fear is that they'll pay for more than we work for! $(\mathrm{M}, 33,8)$

There is a psychological barrier: will the person really work? Remote work scares them (clients) until a relationship based on trust has been established. (F, 35, 1)

Therefore, it seemed that trust and visibility were essential to explain why selfemployed workers' operational autonomy was often limited, especially when work was paid by the hour. Indeed, when they were paid a fixed amount for the duration of the contract, it was easier for them to gain operational autonomy. The client was interested in the final product or service and much less in the way it was achieved.

Our results show that strategic and operational autonomies were correlated to different factors. Our general hypothesis-that the work autonomy of IT self-employed workers depends on contextual factors (clients) and on personal factors (expertise and experience)-is confirmed. Strategic autonomy was correlated to individual characteristics associated with qualification and expertise. On the other hand, operational autonomy was correlated to contextual factors (type of contract, type of client). Operational autonomy did not depend on individual characteristics but on contextual characteristics. Consequently, our respondents may be able to increase their operational autonomy by choosing their clients and promoting fixed-price contracts. Strategic autonomy, however, appeared easier to negotiate for a group of educated IT professionals with valuable expertise. 
Table 3: Work places (hours per week)

\begin{tabular}{|c|c|c|c|}
\hline & $\begin{array}{l}\text { Current } \\
\text { distribution } \\
\text { of workplaces }\end{array}$ & $\begin{array}{l}\text { Ideal } \\
\text { distribution } \\
\text { of workplaces }\end{array}$ & Variance \\
\hline Hours worked at home & $4 h 30$ & $17 \mathrm{~h} 36$ & $+13 \mathrm{~h} 06$ \\
\hline Hours worked at the client's & 32h18 & $17 \mathrm{~h} 24$ & $-14 h 54$ \\
\hline Hours worked somewhere else & $1 \mathrm{~h} 42$ & $2 \mathrm{~h} 42$ & $+1 \mathrm{~h} 00$ \\
\hline Total & $38 \mathrm{~h} 30$ & $37 \mathrm{~h} 42$ & $-0 \mathrm{~h} 48 \mathrm{~min}$ \\
\hline
\end{tabular}

\section{A limitation to operational autonomy: the choice of workplaces}

This last section examines a particular limitation to operational autonomy: the choice of the workplace. As can be seen in Table 1, the independence of IT selfemployed workers was highly constrained as concerns workplace. It was quite surprising because our respondents seemed to enjoy some freedom with respect to important aspects of their operational autonomy, for example, vacation periods or work procedures and technique. Choosing the workplace seemed to be the area in which IT self-employed workers were imposed the most limits to their independence.

As can be seen in Table 3, the results of the questionnaire highlighted a very strong demand for telework. This demand often remained unanswered. When questioned on their preference in terms of workplace, most respondents stated that they should be given the possibility to work at home more often. The difference between actual and preferred workplaces was significant. On the average, respondents wished to work 17 hours and 36 minutes per week at home, 13 hours more than they were allowed. Also, for 46 per cent of the respondents, the workplace was determined by the client, 11 per cent decided by themselves, and 42 per cent negotiated the terms and conditions regarding their workplace.

Respondents were often compelled to abide by the clients' requirements with regard to the distribution of workplaces. This lack of operational autonomy regarding the choice of the workplace was surprising. First, in order to increase their control over the allocation of their time, IT self-employed workers expected to be able to take advantage of the potential offered by ICTs. And second, the unsatisfied demand for telework implicitly questioned the interdependence between self-employed workers and their clients. Consequently, the choice of workplace appears to constitute an important issue.

When asked why they encountered problems with telework in spite of the relevant legal provision allowing them to 'determine the location at which the work is to be carried out and the hours of work', our respondents said their clients put forward technical issues: data security and unavailability of remote access. Although technical reasons were most frequently cited, some IT self-employed workers questioned its relevance and suspected that clients required their presence at the office mainly to control them as they do for regular employees. Other reasons to refuse telework were the client's mistrust, the absence of organisational policies and finally the nature of the work to be done. There was nevertheless one outstanding element among the reasons mentioned to explain the refusal of telework, and that was the dependence between the self-employed workers and their clients. This means that the workforce shortage in IT is beneficial to independent workers, but even in this context, they cannot afford to ignore their clients' requirements regarding work location and the clients often want to have them on site because of the interdependence of tasks. 


\section{Discussion}

The results of this research are a contribution to the study of self-employment in the IT sector. We found that strategic autonomy (i.e. the ability to choose or negotiate one's work objectives, deadlines and financial aspects) was linked to individual factors, education and expertise, whereas operational autonomy (the ability to choose work techniques and procedures, workplace, periods of holidays, equipment and tools) was correlated to contextual factors such as the type of clients and the kind of contracts.

Surprisingly, it was in the choice and determination of the work location that IT workers had the most constraints because of clients' requirements. For a majority of respondents, the ideal distribution of work locations would be $50-50$ between the clients' office and telework. Yet our results indicated that IT self-employed workers performed only a few hours work per week from their home, even if they would have liked to do more.

This study thus highlighted constraints imposed on the autonomy of IT selfemployed workers. The strategic autonomy of the less qualified IT self-employed workers was limited by individual factors (lack of specific qualification and expertise). On the other hand, operational autonomy was contingent on the client and the type of contract. These findings are consistent with those of Marler et al. (2002) and those of Peel and Inkson (2004), who identified expertise and clients as key factors that influence the working conditions of the self-employed. In line with the dichotomy of Marks and Scholarios (2007), we found a polarisation of IT selfemployed workers between 'professionals', who enjoy a greater degree of strategic autonomy, and 'technicians' with a lower degree of strategic autonomy. However, this dichotomy was less clear as concerns operational autonomy, which tends to give support to Westenholz's (2006) proposition: different models (precarious, free agent or professional) may be relevant for different aspects of working conditions for the IT self-employed. In this particular case, different models may be relevant for different aspects of work autonomy.

Our results question the scope of work autonomy, including that of self-employed workers, and leads us to support the use of the concept of discretion (de Terssac and Maggi 1996). Self-employed IT workers negotiate their work autonomy in a discretionary context made of constraints and discussions with their clients. The interdependent relationships thus shaped between self-employed workers and clients highlight the weaknesses of the portfolio - or purely independent model (Smeaton, 2003; D'Amours and Crespo, 2004). This tends to reinforce the hypothesis of a blurring of organisational boundaries (Robinson and Miner, 1996). The findings also support the analyses pointing to hybrid forms of employment. Moreover, the strong demand for telework, considered part of operational autonomy, is the source of individual and social challenges. Where IT self-employed workers are concerned, it is not so much for lack of desire of the self-employed to use telework but for the technical, organisational and cultural issues put forward by the clients that telework is refused or difficult to access. Accordingly, an interesting line for further research could be to examine the strategies developed by self-employed workers in their negotiations for more appropriate workplace arrangements.

Our quantitative results present a very acceptable external validity with respect to the reference population, the members of the AQIII, but the qualitative results do not permit generalisation at this point, although they offer interesting insights for future research. It would therefore be interesting to extend the research into a longitudinal survey of the same population and observe how the strategic and operational dimensions of autonomy evolve. Finally, a similar study of other groups of self-employed workers would undeniably produce interesting results given the heterogeneity of the self-employed population. Nevertheless, let us mention that the shortage of IT workers in many places, including in our study, is a contextual factor that should be taken into consideration to assess the overall degree of the work autonomy of IT self-employed workers, especially in international comparisons. 


\section{Notes}

1. In percentage of employed persons, self-employed workers account for 16 per cent in Canada and 13 per cent in the province of Québec (OECD, 2003); these percentages are similar to those of other industrialised countries; 15 per cent in the European Union and 17 per cent in the OECD.

2. The research was carried out in the Canadian province of Quebec; we refer here to Quebec provincial legislation.

\section{References}

Alvesson, M. and H. Willmott (2002), 'Identity Regulation as Organizational Control: Producing the Appropriate Individual', Journal of Management Studies 39, 5, 619-644.

Ang, S. and S.A. Slaughter (2001), 'Work Outcomes and Job Design for Contract versus Permanent Information Systems Professionals on Software Development Teams', MIS Quarterly 25, 3, 321-350.

Arthur, M. and D. Rousseau (1996), The Boundaryless Career: A New Employment Principle for New Organizational Era (Oxford: Oxford University Press).

Beaucage, A. and E. Najem (2006), 'Une analyse longitudinale de la perennite des experiences des travailleuses et des travailleurs autonomes canadiens', Relations Industrielles/Industrial Relations 61, 2, 321-348.

Beaucage, A. and G. Bellemare (2007), 'De la diversité du succès des expériences de travail autonome au Québec', Recherches Sociographiques 48, 2, 11-36.

Beaucage, A., N. Laplante and R. Légaré (2004), 'Le passage au travail autonome: choix impose ou choix qui s'impose', Relations Industrielles/Industrial Relations 59, 2, 345-378.

Blanchflower, D.G. (2000), 'Self-Employment in OECD Countries', Labour Economics 7, 5, 471-505.

Boden, R. Jr (1999), 'Gender Inequality in Wage Earnings and Female Self-Employment Selection', The Journal of Socio-Economics 28, 3, 351-364.

Bradley, D.E. and J.A. Roberts (2004), 'Self-Employment and Job Satisfaction: Investing the Role of Self-Efficacy, Depression and Seniority', Journal of Small Business Management 42, 1, 37-58.

Breaugh, J.A. (1999), 'Further Investigation of the Work Autonomy Scales: Two Studies', Journal of Business and Psychology 13, 3, 357-373.

Cappelli, P. (2001), 'Why Is It So Hard to Find Information Technology Workers?' Organizational Dynamics 30, 2, 87-99.

Castells, M. (2000), The Rise of the Network Society (Oxford: Blackwell).

D'Amours, M. and S. Crespo (2004), 'Les dimensions de l'heterogeneite de la categorie de travailleur independant sans employe: elements pour une typologie', Relations Industrielles/ Industrial Relations 59, 3, 459-489.

Delage, B. (2002), Résultats De l'Enquête Sur Le Travail Indépendant Au Canada (Ottawa: Développement des ressources humaines Canada (DRHC)).

Donnely, R. (2006), 'How "Free" Is the Free Worker?' Personnel Review 35, 1, 78-97.

Evans, J.A., G. Kunda and S.R. Barley (2004), 'Beach Time, Bridge Time, and Billable Hours: The Temporal Structure of Technical Contracting', Administrative Sciences Quarterly 49, 1-38.

Felstead, A. and N. Jewson (2000), In Home, at Work, towards an Understanding of Homeworking (London: Routledge).

Felstead, A., N. Jewson, A. Phizacklea and S. Walters (2002), 'The Option to Work at Home: Another Privilege for the Favoured Few?' New Technology, Work and Employment 17, 3, 204-223.

Fincham, R. (2006), 'Knowledge Work as Occupational Strategy: Comparing IT and Management Consulting', New Technology, Work and Employment 21, 1, 16-28.

Guérin, G., T. Wils and L. Lemire (1999), 'le dilemme autonomie controle chez les professionnels syndiques quebecois', Revue De Gestion Des Ressources Humaines 31-33, 62-78.

Guest, D., P. Oakley, M. Clinton and A. Budjanovanin (2006), 'Free or Precarious? A Comparison of the Attitudes of Workers in Flexible and Traditional Employment Contracts', Human Resources Management Review 16, 107-124.

Hamilton, B.H. (2000), 'Does Entrepreneurship Pay? An Empirical Analysis of the Returns to Self-Employment', Journal of Political Economy 108, 31, 604-631.

Heller Clain, S. (2000), 'Gender Differences in Full-Time Self-Employment', Journal of Economics and Business 52, 1, 499-513.

Hundley, G. (2001), 'Why Women Earn Less than Men in Self-Employment', Journal of Labor Research 22, 4, 817-829.

Hyytinen, A. and O.-P. Ruuskanen (2007), 'Time Use of the Self-Employed', Kyklos 60, 1, 105-122.

Inkson, K. and M. Arthur (2001), 'How to Become a Successful Career Capitalist', Organizational Dynamics 30, 1, 48-61. 
Janz, B.D., J.A. Colquitt and R.A. Noe (1997), 'Knowledge Worker Team Effectiveness: The Role of Autonomy, Interdependence, Team Development, and Contextual Support Variables', Personnel Psychology 50, 4, 877-904.

Kunda, G., S.R. Barley and J.A. Evans (2002), 'Why Do Contractors Contract? The Experience of Highly Skilled Technical Professionals in a Contingent Labour Market', Industrial and Labor Review 55, 2, 234-261.

Lepak, D.P. and S.A. Snell (1999), 'The Human Resource Architecture toward a Theory of Human Capital Allocation and Development', Academy of Management Review 24, 1, 31-48.

Loscocco, K.A. (1997), 'Work-Family Linkages among Self-Employed Women and Men', Journal of Vocational Behavior 50, 2, 204-226.

Marks, A. and D. Scholarios (2007), 'Revisiting Technical Workers: Professional and Organisational Identities in the Software Industry', New Technology, Work and Employment 22, 2, 98117.

Marler, J.H., M.W. Barringer and G.T. Milkovich (2002), 'Boundaryless and Traditional Contingent Employees: Worlds Apart', Journal of Organizational Behavior 23, 4, 425-453.

Moore, C.S. and R.E. Mueller (2002), 'The Transition from Paid to Self-Employment in Canada: The Importance of Push Factors', Applied Economics 34, 6, 791-801.

OECD (2003), Perspectives de l'emploi (Paris: OECD).

Parasuraman, S. and C. Simmers (2001), 'Type of Employment, Work-Family Conflict and WellBeing: A Comparative Study', Journal of Organizational Behavior 22, 5, 551-568.

Peel, S. and K. Inkson (2004), 'Contracting and Careers: Choosing between Self and Organizational Employment', Career Development International 9, 6, 542-558.

Revenu Québec (2007), Qu'est-ce qu'un travailleur autonome? Revenu Québec.

Robinson, D. and A. Miner (1996), 'Careers Change as Organizations Learn', in M. Arthur and D. Rousseau (eds), The Boundaryless Career: A New Employment Principle for New Organizational Era (Oxford: Oxford University Press), pp. 76-94.

Rogers, J. (2000), Temps: The Many Faces of the Changing Workplace. (New York, NY: Cornell University Press).

Rose, M. (2002), 'IT Professionals and Organisational Ascendancy: Theory and Empirical Critique', New Technology, Work and Employment 17, 3, 154-169.

Smeaton, D. (2003), 'Self-Employed Workers: Calling the Shots or Hesitant Independents? A Consideration of the Trends', Work, Employment \& Society 17, 2, 379-391.

Stanworth, C. and J. Stanworth (1997), 'Managing an Externalised Workforce: Freelance LabourUse in the UK Book Publishing Industry', Industrial Relations Journal 28, 10, 43-55.

Tal, B. (2008), An Island of Stability. Canadian Employment Quality Index, CIBC World Markets. de Terssac, G. (1992), Autonomie Dans Le Travail (Paris: PUF.).

de Terssac, G. and B. Maggi (1996), 'Autonomie et conception', in G. de Terssac and E. Friedberg (eds), Coopération Et Conception (Toulouse: Octarès Éditions), pp. 250-278.

Tremblay, D.-G. (2004), Economie du travail. Les realites et les approches theoriques, édition revue (Montréal: Editions Saint-Martin et Descarries éditeur).

Tremblay, D.-G. (2008), 'From Casual Work to Economic Security; The Paradoxical Case of Self-Employment', Social Indicators Research 88, 115-130.

Tremblay, D.-G., C. Chevrier and M. Di Loreto (2006), 'Le teletravail comme façon de concilier la vie personnelle et la vie professionnelle?' Interventions Économiques 34, 24.

Tremblay, D.-G. and É. Genin (2007), 'The Demand for Telework of IT Self-Employed Workers', Journal of E-Working 1, 2.

Van Gelderen, M. and P. Jansen (2006), 'Autonomy as a Start-Up Motive', Journal of Small Business and Enterprise Development 13, 1, 23-32.

Westenholz, A. (2006), 'Working Conditions of Temporary Company-Affiliated IT Workers', New Technology, Work and Employment 21, 1, 29-42.

Willmott, H. (1993), 'Strength Is Ignorance; Slavery Is Freedom: Managing Culture in Modern Organizations', Journal of Management Studies 30, 4, 515-552. 


\section{Appendix: Factor analysis}

Factor analysis

Communalities

\begin{tabular}{lcc}
\hline & Initial & Extraction \\
\hline Deadlines & 1.000 & 0.714 \\
Outcomes & 1.000 & 0.678 \\
Budget & 1.000 & 0.636 \\
Workplace & 1.000 & 0.612 \\
Holidays & 1.000 & 0.529 \\
Tools & 1.000 & 0.603 \\
Procedures & 1.000 & 0.591 \\
\hline
\end{tabular}

Extraction method: principal component analysis.

Total variance explained

\begin{tabular}{|c|c|c|c|c|c|c|c|c|c|}
\hline \multirow[t]{2}{*}{ Component } & \multicolumn{3}{|c|}{ Initial eigenvalues } & \multicolumn{3}{|c|}{$\begin{array}{l}\text { Extraction sums of } \\
\text { squared loadings }\end{array}$} & \multicolumn{3}{|c|}{$\begin{array}{l}\text { Rotation sums of } \\
\text { squared loadings }\end{array}$} \\
\hline & Total & $\begin{array}{l}\% \text { of } \\
\text { variance }\end{array}$ & $\begin{array}{l}\text { Cumulative } \\
\%\end{array}$ & Total & $\begin{array}{l}\% \text { of } \\
\text { variance }\end{array}$ & $\begin{array}{l}\text { Cumulative } \\
\%\end{array}$ & Total & $\begin{array}{l}\% \text { of } \\
\text { variance }\end{array}$ & $\begin{array}{l}\text { Cumulative } \\
\%\end{array}$ \\
\hline 1 & 3.138 & 44.824 & 44.824 & 3.138 & 44.824 & 44.824 & 2.451 & 35.021 & 35.021 \\
\hline 2 & 1.226 & 17.511 & 62.335 & 1.226 & 17.511 & 62.335 & 1.912 & 27.314 & 62.335 \\
\hline 3 & 0.752 & 10.747 & 73.082 & & & & & & \\
\hline 4 & 0.588 & 8.397 & 81.480 & & & & & & \\
\hline 5 & 0.523 & 7.465 & 88.944 & & & & & & \\
\hline 6 & 0.426 & 6.083 & 95.027 & & & & & & \\
\hline 7 & 0.348 & 4.973 & 100.000 & & & & & & \\
\hline
\end{tabular}

Extraction method: principal component analysis.

Rotated component matrix

\begin{tabular}{lll}
\hline & Component & \\
\cline { 2 - 3 } & 1 & 2 \\
\hline Deadlines & 0.845 & \\
Outcomes & 0.795 & 0.601 \\
Budget & 0.786 & 0.726 \\
Workplace & & 0.768 \\
Holidays & & 0.609 \\
Tools & &
\end{tabular}

Extraction method: principal component analysis.

Rotation method: varimax with kaiser normalization.

aRotation converged in 3 iterations. 


\begin{tabular}{lrr}
\hline Component & \multicolumn{1}{c}{1} & \multicolumn{1}{c}{2} \\
\hline 1 & 0.801 & 0.599 \\
2 & -0.599 & 0.801 \\
\hline
\end{tabular}

Extraction method: principal component analysis.

Rotation method: varimax with kaiser normalization.

Reliability factor 1: strategic autonomy

Case processing summary

\begin{tabular}{llrr}
\hline & & $\mathrm{N}$ & $\%$ \\
\hline \multirow{2}{*}{ Cases } & & 109 & 55.6 \\
& Valid & 87 & 44.4 \\
& Excluded $^{\mathrm{a}}$ & 196 & 100.0 \\
& Total & & \\
\hline
\end{tabular}

${ }^{a}$ Listwise deletion based on all variables in the procedure.

Reliability statistics

Cronbach's alpha

No. of items

0.786

3

Factor 2: operational autonomy

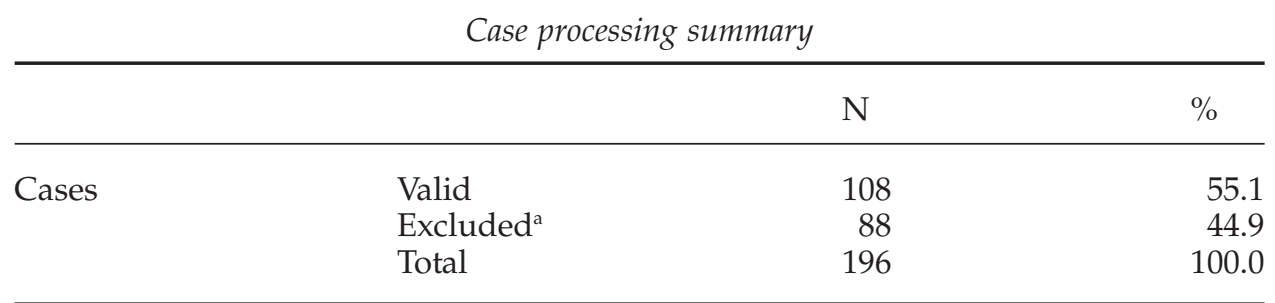

${ }^{\mathrm{a}}$ Listwise deletion based on all variables in the procedure.

Reliability statistics

Cronbach's alpha

No. of Items

0.709

4 